\title{
Immunomodulator Activity of Effervescent Granule of Wualae Fruit (Etlingera elatior (Jack) R.M. Smith) Based on Specific Phagocytic Activity
}

Adryan Fristiohady
Wa Ode Siti Zubaydah
Wahyuni
Mirda
Saripuddin
Rina Andriani
La Ode Muhammad Julian
Purnama
Sahidin* 10
Department of Pharmacy, Universitas
Halu Oleo, Kendari, South East
Sulawesi, Indonesia
*email: sahidin02@uho.ac.id
Keywords:
Effervescent Granule
Phagocytosis Activity
Wualae Fruit

\begin{abstract}
The previous study reported that Etlingera elatior (Wualae) has activity as immunostimulant with dose at $300 \mathrm{mg} / \mathrm{kg} \mathrm{BW}$ and $400 \mathrm{mg} / \mathrm{kg}$ BW. Formulating natural product into effervescent granule (EG) can increase practicality and interest to consume traditional medicine. This study aims to investigate the immunostimulant activity of Wualae ethanolic extract in the effervescent granule. Wualae was macerated with ethanol then formulated into effervescent granule at dose 300 $\mathrm{mg} / \mathrm{kgBW}$ and $400 \mathrm{mg} / \mathrm{kgBW}$. Formulations were evaluated. Animals were divided into four groups and treated with: group I (positive control); group II (negative control); group III (EG dose at $300 \mathrm{mg} / \mathrm{kgBW}$ ); and group IV (EG at dose $400 \mathrm{mg} / \mathrm{kgBW}$ ) for seven days and on the eighth day, groups were infected by Staphylococcus aureus intraperitoneally. Immunostimulant activity was measured by calculating the Specific Phagocytic Activity (SPA) of macrophage. Data collected from the evaluation and measurement of the SPA then analyzed using SPSS. Results from the evaluation were considered good except the moisture content of effervescent granule. Results from SPA was found that effervescent granule at dose $300 \mathrm{mg} / \mathrm{kgBW}$ and at dose $400 \mathrm{mg} / \mathrm{kgBW}$ have $26.33 \%$ and $32.5 \%$ consecutively with significance $0.02(\mathrm{p}<0.05)$. Thus, effervescent granule has comparable phagocytosis activity with positive control.
\end{abstract}

Received: July 14th 2019

Accepted: October 12th 2019

Published: November $14^{\text {th }} 2019$

(c) 2019 Adryan Fristiohady, Wa Ode Siti Zubaydah, Wahyuni, Mirda, Saripuddin, Rina Andriani, La Ode Muhammad Julian Purnama, Sahidin. Published by Institute for Research and Community Services Universitas Muhammadiyah Palangkaraya. This is an Open Access article under the CC-BY-SA License (http://creativecommons.org/licenses/by-sa/4.0/). DOI: https://doi.org/10.33084/bjop.v2i2.868.

\section{INTRODUCTION}

Indonesia is a megabiodiversity country where almost all of its natural resources can be utilized as traditional medicines. Etlingera elatior or wualae, in local name, is a family of Zingiberaceae which can be found in Indonesia. Wualae can be utilized as source food and traditional medicine, which almost all of part of wualae from the rhizome to flower can be used (Chan et al., 2011). Active compounds can be found in wualae are tannins, terpenoids, saponins, flavonoids, and carbohydrates. The essential oil also detected in wualae (Lachumy et al., 2010; Jaafar et al., 2007).
The results from previous study showed that wualae has activity as immunostimulant with dose at $300 \mathrm{mg} / \mathrm{kg}$ BW and $400 \mathrm{mg} / \mathrm{kg}$ BW consecutively with higher dose gives higher effect. Phytochemical screening indicated that wualae contains flavonoids which potentially have activity as an immunomodulator (Wahyuni et al., 2017). An immunomodulator is a compound that can enhance the immune system of humans that classify into three groups, consisting of immunostimulatory, immunoregulator, and immunosuppressor. Immunostimulator can enhance the function and activity of the immune system, immunoregulator can regulate 
the immune system, and immunosuppressor can hamper and ease the immune system if the function is overworked (Murphy, 2012).

The proper formulation in processing natural products into the dosage form who acceptable by society can be expected to increase practicality and the interest to consume traditional medicine. Producing natural products into the extract and formulate them into effervescent granule is an option. This is because, the effervescent granule is easier to consume for people who have difficulty to have tablets or capsules and it dissolves entirely in water thus it will have better absorption hence have the onset of action faster, improved palatability, and have good tolerance in the stomach and intestinal. They are intended to be dissolved or dispersed in water before administration (Anwar, 2010; Patel \& Siddaiah, 2018; British Pharmacopoeia Commission, 2009). No study has been reported about the immunostimulant activity of ethanolic extract of wualae fruit as effervescent granule, so this study aims to investigate the effect of the immunostimulant activity of ethanolic extract of wualae fruit as an effervescent granule.

\section{MATERIALS AND METHODS}

\section{Wualae fruit collection}

Wualae fruit samples were collected from Kalu-kaluku Village of Kodeoha Sub-District, North Kolaka District, Southeast Sulawesi, Indonesia. Collected samples were sorted from their stalks then washed by running water. The samples then dried in under sun exposure covered by a black cloth.

\section{Wualae fruit extraction}

The dried wualae fruit samples $(2.1 \mathrm{~kg})$ were macerated with ethanol 96\% (Merck®) for three times each for 24 hours and filtered using Whatman filter papers. Their filtrates were concentrated under reduced pressure, and $124.8 \mathrm{~g}$ ethanolic extract of wualae fruit yielded.

\section{Preparation of effervescent granule}

Effervescent granule was made in three formulas which are effervescent granule without containing wualae fruit ethanolic extract (Formula I), effervescent granule contain dose at $300 \mathrm{mg}$ wualae fruit ethanolic extract (Formula II), and effervescent granule contain dose at 400 mg wualae fruit ethanolic extract (Formula III). Wet granulation is the method chosen in this formulation.

Effervescent granule was carried out by the dried extract of wualae fruit was softened and then blended with sodium bicarbonate $\left(\right.$ Merck $\left.^{\circledR}\right)$, tartaric acid $\left(\right.$ Merck $\left.^{\circledR}\right)$, citric acid $\left(\operatorname{Merck}^{\circledR}\right)$, aspartame $\left(\operatorname{Merck}^{\circledR}\right), \operatorname{PVP}\left(\operatorname{Merck}^{\circledR}\right)$, and added with lactose $\left(\operatorname{Merck}^{\circledR}\right)$. The powder is granulated by being moistened with $96 \%$ ethanol $\left(\right.$ Merck $\left.^{\circledR}\right)$ and sieved through 14-mesh sieved. After that, the granule dried in the oven for about three hours at $40^{\circ} \mathrm{C}$ and the dry granule was sieved through 16-mesh sieved. Granule was stored and sealed tightly for further evaluation. Ingredients used in formulations are presented in Table I.

Table I. Effervescent granule with wualae fruit ethanolic extract formulation

\begin{tabular}{llccc}
\hline \multirow{2}{*}{ Ingredients } & Category & \multicolumn{3}{c}{ Formula } \\
\cline { 3 - 5 } & & I & II & III \\
\hline Wualae & Active & - & $300 \mathrm{mg}$ & $400 \mathrm{mg}$ \\
ethanolic & ingredient & & & \\
extract & & & & \\
Sodium & Base source & $43.18 \%$ & $43.18 \%$ & $43.18 \%$ \\
bicarbonate & & & & \\
Tartaric acid & Acid source & $20.68 \%$ & $20.68 \%$ & $20.68 \%$ \\
Citric acid & Acid source & $11.68 \%$ & $11.68 \%$ & $11.68 \%$ \\
Aspartame & Sweetener & $0.5 \%$ & $0.5 \%$ & $0.5 \%$ \\
PVP & Binder & $3 \%$ & $3 \%$ & $3 \%$ \\
Lactose ad & Filler & $100 \%$ & $100 \%$ & $100 \%$ \\
\hline
\end{tabular}

\section{Evaluation of effervescent granule}

Organoleptic test

The organoleptic evaluation was performed by observing the taste, color, and odor of granule.

\section{Moisture content test}

The moisture content evaluation was performed by weighting the wet and dried granule. 


\section{Dissolve time evaluation}

The dissolution time evaluation was performed by observing how much time is needed by the effervescent granule disperse in water.

pH test

The $\mathrm{pH}$ evaluation was performed by using a $\mathrm{pH}$ meter.

Flow test

The flow test was performed by measuring the flow time and angle of repose of granule formed.

\section{Animals and ethics}

Male albino mice (20-30 g) used in this study were obtained from the animal farm in Surabaya, Indonesia. Animals were acclimatized for seven days to study in advance. Animals were put in a new environment under standard environmental conditions with meet temperature $\left(25 \pm 1^{\circ} \mathrm{C}\right)$, humidity $(55 \pm 5 \%)$, and darklight cycle (12:12). All experiments involving animals in this study were conducted following the Animal Ethics Committee of Universitas Halu Oleo (No.248/UN29.20/PPM/2019).

\section{Experimental design}

After seven days of acclimatization, 30 male mice were divided into four groups (group I - IV) and treated orally for the next seven days with the following treatment:

Group I : Positive control (Stimuno ${ }^{\circledR 1000)}$

Group II : Negative control (Formula I)

Group III : Treated control (Formula II)

Group IV : Treated control (Formula III)

On the eighth day, each animal from designated groups was infected by Staphylococcus aureus intraperitoneal. After an hour, animals were euthanized with ether $\left(\right.$ Merck $\left.^{\circledR}\right)$, and abdominal surgery was performed to collecting peritoneal solution and adding sterile phosphate-buffered saline (PBS) pH 7.8 solutions. After that, the solution was put in the object-glass and fixated using methanol (Merck $\left.{ }^{\circledR}\right)$ for five minutes then colored by $10 \%$ Giemsa $\left(\right.$ Merck $\left.^{\circledR}\right)$ for 20 minutes and rinsed with running water.

\section{Measurement of phagocytic activity}

Immunostimulant activity was measured by calculating the Specific Phagocytic Activity (SPA) of macrophage under the light microscope (Olympus ${ }^{\circledR}$ ) with magnification from $10 x$ to $1000 x$. The formula of SPA $=$ (active macrophages : total macrophages) $\times 100 \%$ (Marusin \& Chairul, 2012).

\section{Statistical analysis}

Results were statistically analyzed using the Statistical Product and Service Solution (SPSS) Statistics 21.0. The data among groups was carried out using One-way ANOVA (statistically significant, if value sig <0.05), followed by post hoc Tukey (statistically significant, if values $\mathrm{p}<0.05)$. Kruskal-Wallis will be done if data were not normally distributed, and the data can be continued with Mann-Whitney.

\section{RESULTS AND DISCUSSION}

The effervescent granule is solid dosage form which is uncoated granule generally containing acid substances and carbonates or hydrogen carbonates which react rapidly in the presence of water to release carbon dioxide, and they are intended to be dissolved or dispersed in water before administration (British Pharmacopoeia Commission, 2009). Effervescent granule was chosen for this formulation in consideration of patients who experience difficulty swallowing tablets or capsules, and it dissolves entirely in water. Thus, it will have better absorption, the onset of action faster, improved palatability, and good stomach and intestinal tolerance (Patel \& Siddaiah, 2018).

Wualae fruit ethanolic extract was formulated into effervescent granule with dose $300 \mathrm{mg} / \mathrm{kg}$ BW and 400 $\mathrm{mg} / \mathrm{kg}$ BW respectively. The selection of dose in the 
formulation of the effervescent granule is based on the previous study (Wahyuni et al., 2017). The effervescent granule was formulated into different dose to find the correlation of dose and its activity as an immunostimulant by its phagocytosis activity. The evaluations were carried out in this study are organoleptic, moisture content, dissolve time, $\mathrm{pH}$ test, and flow test evaluation (van Riet-Nales et al., 2016; Liu et al., 2019).

Based on evaluation was performed in formulas to observe the taste, color, and odor. The formula II (F II) and III (F III) have color and odor wualae-like. This is caused by added wualae ethanolic extract into formulas compared with formula I (F I). The result of organoleptic evaluations presented in Table II.

Table II. The result of organoleptic evaluation

\begin{tabular}{cccc}
\hline Formula & Taste & Color & Odor \\
\hline I & Sweet and sour & White & Base specific \\
II & Sweet and sour & Light & Typical \\
& & brown & Wualae \\
III & Sweet and sour & brown & Typical \\
& & & Specific \\
\hline
\end{tabular}

Table III presented that the moisture content of granule at $2.05 \%$ (F I), $2.76 \%$ (F II), and 3.27\% (F III) have higher moisture content than standard. Dissolve time of effervescent granule was considered reasonable because of the time needed to dissolve the effervescent granule in water under five minutes, consisting of 04:09 minutes ( $F$ I); 04:10 minutes (F II); and 04:27 minutes (F III). The pH results from the evaluation showed that effervescent granule meets the requirement with values between 6-7. Results obtained from the angle of repose (a) were shown in Table III, which values $21.42^{\circ}$ (F I), $21.37^{\circ}$ (F II), and $21.03^{\circ}(\mathrm{F} \mathrm{III)}$.
Table III. The result of effervescent granule evaluation

\begin{tabular}{lccc}
\hline \multirow{2}{*}{ Evaluation } & \multicolumn{3}{c}{ Formula } \\
\cline { 2 - 4 } & I & II & III \\
\hline Moisture Content (\%) & 2.05 & 2.76 & 3.27 \\
Dissolve time (minutes) & $4: 09$ & $4: 10$ & $4: 27$ \\
$\mathrm{pH}$ & 6.16 & 6.31 & 6.01 \\
flow rate & 44.4 & 50.0 & 50.0 \\
Angle of repose $\left(^{\circ}\right)$ & 21.42 & 21.37 & 21.03 \\
\hline
\end{tabular}

Moisture content has a critical role in effervescent granule since it affects the chemical reaction of acid and base source, and it affects the stability of granule (Swarbick, 2013). The dissolving time of effervescent granule is needed to observing the rate of granule dissolves in water, and the result is considered good because result obtained is less than five minutes (British Pharmacopoeia Commission, 2009). The $\mathrm{pH}$ test needed for observing the acidity and base level of effervescent granule and the result of study meet the requirement (Swarbick, 2013). The flow test was performed with flow rate and angle of repose of effervescent granule. Results obtained from the angle of repose (a) indicate that formulations are freeflowing granule. The flow rate was affected by particle size and its distribution, shape, density, and moisture content (Patel \& Siddaiah, 2018).

The flavonoid in ethanolic extract of wualae fruit is responsible for the phagocytic activity, which is describing its activity as immunostimulator (Wahyuni et al., 2017). The possible mechanism of flavonoids is improving cellular immune response by improving lymphokine proliferation effectivity (Hosseinzade et al., 2019). Flavonoids potentially stimulate lymphokine, which is produced by T-cell hence stimulate phagocytosis responses process by activating macrophage (Perez-Cano \& Castell, 2016).

An activated macrophage is characterized by spreading macrophages and observed the formation of large vacuoles and modification of round shape, as shown in Figure 1 (Petricevich et al., 2008). Macrophage has a critical role in the immune response by destroying 
bacteria, parasites, viruses and tumour cell directly. Moreover, macrophage can release mediators (IL6 and TNF-a) hence activating other immune cells (Duque \& Descoteaux, 2014).

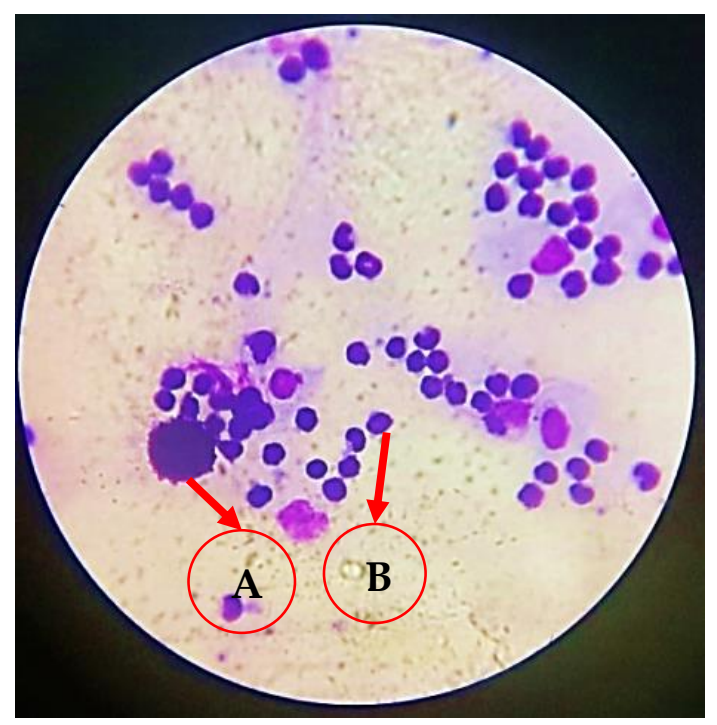

Figure 1. Giemsa-stained thin blood (1000x magnification) of active macrophage (A) and inactive macrophage (B)

Results presented in Table IV show that effervescent granule of wualae fruit ethanolic extracts enhanced phagocytosis activity compared with the negative control. Table IV and Figure 2 showed that the dose depended on specific phagocytosis activity. The dose at $400 \mathrm{mg} / \mathrm{kg}$ BW had a higher effect than at the dose at 300 $\mathrm{mg} / \mathrm{kg} \mathrm{BW}$. Based on the analytical statistic, it was found that effervescent granule (EG) at dose $300 \mathrm{mg} / \mathrm{kg}$ BW and $400 \mathrm{mg} / \mathrm{kg}$ BW have comparable phagocytosis activity with Phyllanthus niruri L. (Stimuno ${ }^{\circledR}$ ) extract. This happened due to the higher dose of flavonoid in ethanolic extract of wualae fruit induce phagocyte cell more active to phagocyte bacteria (Zalizar, 2013).

Table IV. Specific Phagocytosis Activity

\begin{tabular}{lcccc}
\hline \multicolumn{1}{c}{ Treatment } & \multicolumn{3}{c}{ SPA (\%) } & Average (\%) \\
\cline { 2 - 4 } & I & II & III & \\
\hline $\begin{array}{l}\text { Negative } \\
\text { Control }\end{array}$ & 15 & 13 & 15 & 14.33 \\
$\begin{array}{l}\text { Positive } \\
\begin{array}{l}\text { ontrol } \\
\text { EG Dose 300 }\end{array}\end{array}$ & 32 & 33 & 35 & 33.33 \\
mg/kg BW & 27 & 25 & 27 & 26.33 \\
$\begin{array}{l}\text { EG Dose 400 } \\
\text { mg/kg BW }\end{array}$ & 32.5 & 33 & 32 & 32.5 \\
\hline
\end{tabular}

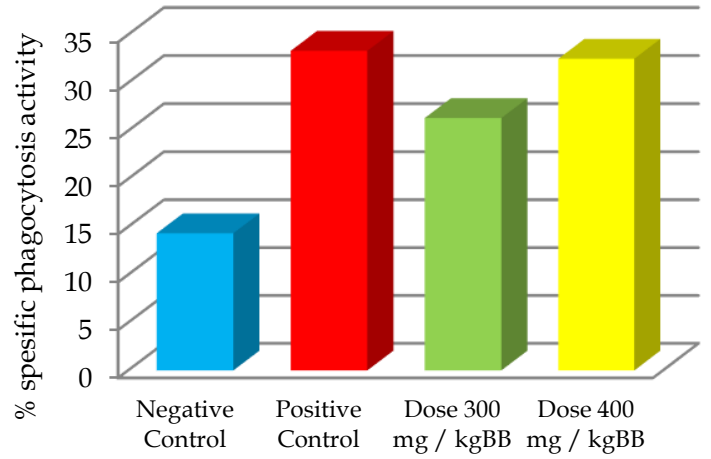

Figure 2. Graphic of \% specific phagocytosis activity of effervescent granules

\section{CONCLUSION}

Evaluations were done in this study conclude that effervescent granule formulated were showing good results except for the moisture content for all formulation. The effervescent granule of wualae fruit at the dose 300 $\mathrm{mg} / \mathrm{kg}$ BW and the dose $400 \mathrm{mg} / \mathrm{kg}$ BW have immunostimulant activity with SPA are $26.33 \%$ and $32.5 \%$, respectively. Further study needed for stable and better formulation.

\section{ACKNOWLEDGMENT}

The author thanks to the Ministry of Research, Technology, and Higher Education of Republic Indonesia for scheme grant research (Penelitian Dasar Unggulan Perguruan Tinggi 2018).

\section{REFERENCES}

Anwar, K. 2010. Formulasi Sediaan Tablet Effervescent dari Ekstrak Kunyit (Curcuma domestica Val.) dengan Variasi Jumlah Asam Sitrat-Asam Tartrat sebagai Sumber Asam. Jurnal Ilmiah Berkala Sains dan Terapan Kimia. 4(2):168-178. http://dx.doi.org/10.20527/jstk.v4i2.2065

British Pharmacopoeia Commission. 2009. British Pharmacopoeia 2009. London: The Stationery Office. 
Chan, E.W.C., Lim, Y.Y., Wong, S.K. 2011. Phytochemistry and Pharmacological Properties of Etlingera elatior: A Review. Pharmacognosy Journal. 3(22):6-10. https://doi.org/10.5530/pj.2011.22.2

Duque, G.A., Descoteaux, A. 2014. Macrophage Cytokines: Involvement in Immunity and Infectious Diseases. Frontiers in Immunology. $\quad \mathbf{5 : 4 9 1 .}$ https:/ / dx.doi.org/10.3389/fimmu.2014 .00491

Hosseinzade, A., Sagedhi, O., Biregani, A.N., Soukhtehzari, A., Brandt, G.S., Esmailzadeh, A. 2019. Immunomodulatory Effects of Flavonoids: Possible Induction of T CD4+ Regulatory Cells Through Suppression of mTOR Pathway Signaling Activity. Frontiers in Immunology. 10:51. https://dx.doi.org/10.3389/fimmu.2019 .00051

Jaafar, F.M., Osman, C.P., Ismail, N.H., Awang, K. 2007. Analysis of Essential Oils of Leaves, Stems, Flowers and Rhizomes of Etlingera elatior (Jack) R. M. Smith. Malaysian Journal of Analytical Sciences. 11(1):269-273.

Lachumy, S.J.T., Sasidharan, S., Sumathy, V., Zuraini, Z. 2010. Pharmacological activity, phytochemical analysis and toxicity of methanol extract of Etlingera elatior (torch ginger) flowers. Asian Pacific Journal of Tropical Medicine. 3(10):769-774. https://doi.org/10.1016/S19957645(10)60185-X

Liu, Z., Sun, X., Liang, T., Luo, Y., Chen, X., Wang, J., Lin, Y., Ye, Y., Zhong, Z. 2019. Preparation and Characterization of the Biological Compound Effervescent Granule of Calcium Acetate. Current Pharmaceutical Biotechnology. 20(11). https:/ / doi.org/10.2174/1389201020666 190628144637

Marusin, S., Chairul, C. 2012. Efek ekstrak air dan alkohol pada siwak (Salvadora persica L.) terhadap peningkatan aktivitas dan kapasitas fagositosis sel makrofag. Media Penelitian dan Pengembangan Kesehatan. 22(1):38-44.
Murphy, K.M. 2012. Janeway's Immunobiology. $8^{\text {th }}$ edition. New York: Garland Science.

Patel, S.G., Siddaiah, M. 2018. Formulation and evaluation of effervescent tablets: a review. Journal of Drug Delivery and Therapeutics. $\quad \mathbf{8 ( 6 ) : 2 9 6 - 3 0 3 . ~}$ https://doi.org/10.22270/jddt.v8i6.2021

Perez-Cano, F.J., Castell, M. 2016. Flavonoids, Inflammation and Immune System. Nutrients. $\quad$ 8(10):659. https://dx.doi.org/10.3390/nu8100659

Petricevich, V.L., Reynaud, E., Cruz, A.H., Possani, L.D. 2008. Macrophage activation, phagocytosis and intracellular calcium oscillations induced by scorpion toxins from Tityus serrulatus. Clinical and Experimental Immunology. 154(3):415-423. https:/ / doi.org/10.1111/j.13652249.2008.03754.x

van Riet-Nales, D.A., Schobben, A.F., Vromans, H., Egberts, T.C., Rademaker, C.M. 2016. Safe and effective pharmacotherapy in infants and preschool children: importance of formulation aspects. Archives of Disease in Childhood. 101(7):662-669. https://doi.org/10.1136/archdischild2015-308227

Swarbick, J. 2013. Encyclopedia of Pharmaceutical Science and Technology, Six Volume Set. $4^{\text {th }}$ edition. Boca Raton: CRC Press.

Wahyuni, Malaka, M.H., Fristiohady, A., Yusuf, M.I., Sahidin. 2017. Potensi Imunomodulator Ekstrak Etanol Buah Kecombrang (Etlingera elatior (Jack) R.M.Smith) terhadap Aktivitas Fagositosis Makrofag Mencit Jantan Galur Balb/C. Pharmacon. 6(3):350-355.

Zalizar, L. 2013. Flavonoids of Phyllanthus Niruri as Immunomodulators a Prospect to Animal Disease Control. ARPN Journal of Science and Technology. 3(5):529-532. 